Review Article

\title{
Micro-health insurance in dentistry: the road less travelled
}

\author{
Naz-E-Farha Hakeem*, Shruthi Eshwar, B. K. Srivastava, Vipin Jain
}

Department of Public Health Dentistry, K.L.E Society's Institute of Dental Sciences, Bangalore, Karnataka, India

Received: 06 January 2019

Revised: 09 February 2019

Accepted: 11 February 2019

\section{*Correspondence:}

Dr. Naz-E-Farha Hakeem,

E-mail: farhahakeem29@gmail.com

Copyright: (C) the author(s), publisher and licensee Medip Academy. This is an open-access article distributed under the terms of the Creative Commons Attribution Non-Commercial License, which permits unrestricted non-commercial use, distribution, and reproduction in any medium, provided the original work is properly cited.

\begin{abstract}
Oral health is indeed a challenge for the urban poor. Majority of the patients spend from their pocket, which aggravates their financial condition. It is paramount for the government and the healthcare industry to adopt a valuebased approach to redress the oral health lapses for the underserved population. Micro health insurance (MHI) can have a game changing effect on the oral healthcare space too, if concerned stakeholders build the right partner network. Aim of the study was to discuss the principal features, basic structure, and functioning of a few MHI schemes, and presents a hypothetical model of MHI which can be implemented in dentistry. Literature search was conducted in two main databases, pubmed and cochrane, using key phrases such as "community based health insurance," "micro health insurance," micro or community based health insurance," and "health insurance and financial protection". Articles published in last ten years with full texts were considered. 23 schemes were eligible for the systematic review. Our analysis shows that MHI, in the majority of cases, contributes to the financial protection of its beneficiaries, by reducing out of pocket health expenditure, catastrophic health expenditure, household borrowings and poverty. However, the studies did not affirm oral health benefits. The importance of oral healthcare in India is superficial. Focus on oral healthcare can be achieved only if the impending cost due to out of pocket payments can be supplanted with a more affordable and dynamic payment model. With MHI extended to oral healthcare, India can certainly achieve its SDG goal. It's time to look beyond.
\end{abstract}

Keywords: MHI, Community health insurance, Financial protection

\section{INTRODUCTION}

Almost every household in developing countries are exposed to a variety of risks. Illness, disability, death, unemployment, crop failure, natural catastrophes, or crime-the risks can manifest in any of the forms. Lowincome households, in particular, are more vulnerable to the risks. That means these low income households are widely exposed to huge healthcare cost. ${ }^{1}$ Families often opt out of regular consultation, diagnostics, and medication due to high out of pocket expenditure. According to economic implications of diseases in 2004 data, Indians had spent 846 billion out of pocket healthcare expenditure around $3.3 \%$ of India's GDP,
With an aim to counter these issues, various healthcare organizations, government agencies, and non-profits are together devising new strategies to prevent people from ignoring healthcare. ${ }^{2}$ Micro insurance being one of the prominent strategies for consumerizing healthcare access. Social protection measures to prevent people falling into the above mentioned risk's include micro insurance. ${ }^{3}$

Healthcare is a human right and it is paramount to ensure its accessibility and affordability. However, increasing costs of healthcare is beyond the reach of common man. ${ }^{4}$ Dental diseases in particular are becoming increasingly fatal owing to the inability of the communities to expend money for treatment. At this juncture, it should be noted 
that there is an uneven distribution of dental diseases around the world. While a majority of children and adults have major health problem in the industrialized countries, there is an alarming increase in level of dental caries in the developing countries, according to the WHO global oral health data bank $2004 .^{5}$

In India, caries experience is high in all age groups and it increases as age advances, says a report by the national oral health survey and fluoride mapping 2002-03. The report indicates that adult males are more susceptible to oral cancer than females. In addition, the condition is more prevalent in rural and urban poor residents. At a time when dental health risks are causing great economic stress on low-income households, strategies such as risk pooling over a large number of people through health insurance schemes can help in overcoming health risks without facing the financial burden. ${ }^{6}$

In India, the informal sector forms more than $90 \%$ of the population. This comprises farmers, labourers, the selfemployed, traders, etc. Currently most of this population has to rely either on the poorly functioning government health facilities or expensive private health services. Obviously, this forms a considerable barrier to healthcare, especially for the weaker sections of society. ${ }^{7}$

Micro-insurance for health is the protection of lowincome people against specific perils in exchange of regular premium payments proportions to the likelihood and cost of the risk involved. The difference between micro-health insurance and the regular health insurance is that the former is specifically targeted at low-income people, especially the urban poor, who have limited financial resources and often irregular income flows. So in order to overcome this financial gap, micro-insurance is been promoted by the government and voluntary agencies. $^{8}$

Objective of the study was to discuss the principal features, basic structure, and functioning of a few micro health insurance (MHI) schemes, and present a hypothetical model for MHI implementation in dentistry.

\section{METHODS}

A systematic review was conducted, for which the principal investigator formulated a search strategy to recognize peer reviewed publications, project evaluations and reports of research studies in which MHI, in one of its organizational settings, which was delivered to low income households.

Review was conducted, from July and August 2018, using combinations of text words and thesaurus terms "community based health insurance," "micro health insurance," micro or community based health insurance," and "health insurance and financial protection" these search terms were entered concurrently, records that were published in the last ten years having full texts that were available free of cost, were considered. The investigator decided to exclude non-English articles to avoid translation costs.

Search filters include original articles, review articles pertaining to medicine and dentistry, nursing and allied and social sciences. The search for cochrane and pubmed, was limited to title and abstract. Further the reference list of the articles was hand searched to shortlist the articles by the above-mentioned strategy. Figure 1 shows the flow of systematic search results.

\section{Inclusion criteria}

Publications and reports were categorised at 3 levels;

- First level-population: low income households.

- Second level-interventions: micro health insurance.

- Third level-outcome: financial protection.

\section{Data collection}

Our search resulted in 1006 papers from the three databases. After title and abstract review of these papers, 23 policies were shortlisted for review of full text to fulfil our inclusion and exclusion criterion. 20 policies/projects that are providing micro health insurance in medical field were included in the final list of articles for data extraction. The author independently assessed the title and abstracts and then reviewed the full texts of the shortlisted papers.

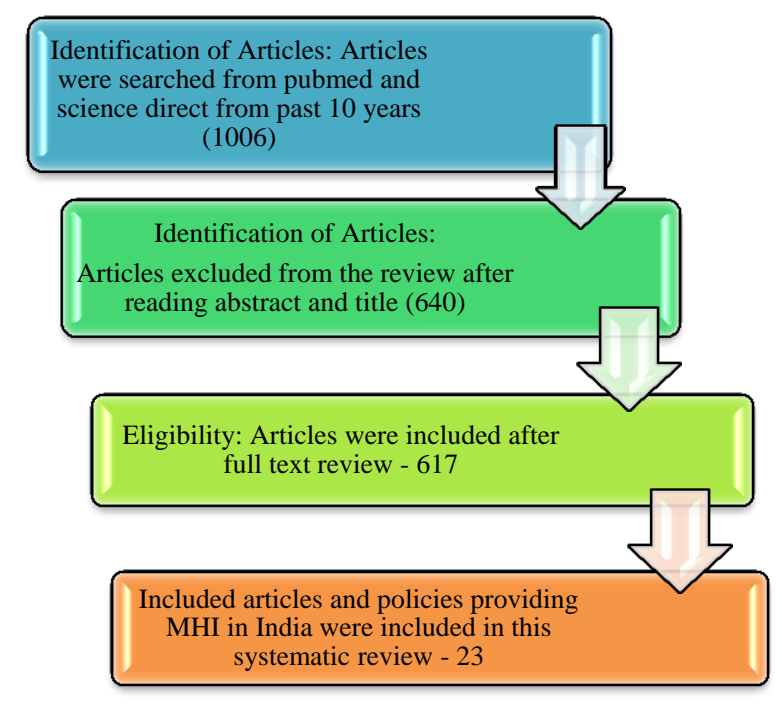

Figure 1: Flowchart-methodology of the study.

\section{Data extraction}

From each article/report included the data collection strategy, target population (low income households), measures of financial protection assessed to identify the key findings. In the final step, we assessed the adequacy and quality of information on the study design, sample 
size of the target population, interventions, evaluation methods and results. Since the study population, organizational setting of health insurance, methodology, evaluation designs and measures of financial protection being evaluated in these studies were heterogeneous; a meta-analysis or quantitative synthesis was not conducted.

\section{RESULTS}

Table 1 provides a list of the programs that were finally included, summarizing name of the MHI project (or the implementing organization), which are including population under scheme, premium to be paid under the scheme, the measure of financial protection assessed and the key findings of the program.

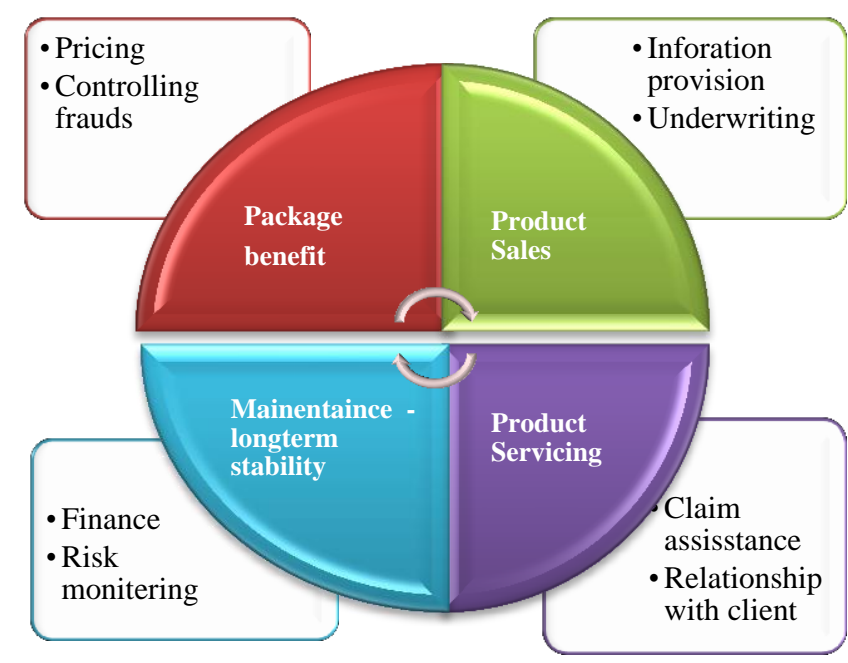

Figure 2: Challenges for micro health insurance schemes.

Table 1: Micro health insurance schemes in India.

\begin{tabular}{|c|c|c|c|}
\hline $\begin{array}{l}\text { Name and location of the } \\
\text { MHI Target } \\
\text { population, year of } \\
\text { initiation as well as type of } \\
\text { model }\end{array}$ & Target population & $\begin{array}{l}\text { Services covered under } \\
\text { the scheme }\end{array}$ & $\begin{array}{l}\text { Premium per year along } \\
\text { the unit of enrolment }\end{array}$ \\
\hline $\begin{array}{l}\text { ACCORD Gudalur, } \\
\text { Nilgiris, Tamil } \\
\text { Nadu, 1992, type I }\end{array}$ & $\begin{array}{l}\text { Scheduled tribes of Gudalur } \\
\text { taluk who are members. } \\
\text { Adivasi munnetra sangam } \\
\text { (AMS) - the tribal union. }\end{array}$ & $\begin{array}{l}\text { Hospitalization coverage } \\
\text { up to Rs } 5000\end{array}$ & Rs 20/per person \\
\hline $\begin{array}{l}\text { Jan Arogya Bima Policy } \\
\text { (Sevashram) 2006, } \\
\text { Tamil Nadu }\end{array}$ & $\begin{array}{l}\text { voluntary scheme covers } \\
125 \text { people in } 1 \text { district of } \\
\text { Ernakulum }\end{array}$ & $\begin{array}{l}\text { Hospitalization charges } \\
\text { up to Rs 5,000/person, per } \\
\text { year }\end{array}$ & $\begin{array}{l}\text { Age segregated premium } \\
\text { options. Up to } 45 \text { years: Rs } \\
\text { 70/person/year. }\end{array}$ \\
\hline $\begin{array}{l}\text { Micro health insurance } \\
\text { scheme } \\
\text { (BISWA) Bharathi } \\
\text { integrated social welfare } \\
\text { agency, Orissa, 2005, type I }\end{array}$ & $\begin{array}{l}\text { Offering to poor households } \\
\text { in rural and urban areas. It } \\
\text { has expanded into } 22 \\
\text { districts of Orissa }\end{array}$ & $\begin{array}{l}\text { maximum sum insured for } \\
\text { hospitalization is Rs } \\
15,000 \text {, up to Rs } 2,500 \text { for } \\
\text { cataract treatment, and Rs } \\
10,000 \text { for accidental } \\
\text { death }\end{array}$ & $\begin{array}{l}\text { Premium of Rs } 325 \text { for a } \\
\text { family of } 4 \text { members }\end{array}$ \\
\hline $\begin{array}{l}\text { Karuna Trust T Narsipur } \\
\text { Block, Mysore district, } \\
\text { Karnataka, 2002, type III }\end{array}$ & $\begin{array}{l}\text { Total population of } \mathrm{T} \\
\text { Narsipur block and } \\
\text { Bailhongal block, with a } \\
\text { focus on scheduled tribes } \\
\text { and scheduled caste } \\
\text { populations. }\end{array}$ & $\begin{array}{l}\text { Hospitalization and OPD } \\
\text { charges are paid up to Rs } \\
5000\end{array}$ & Rs 30/per person \\
\hline $\begin{array}{l}\text { RAHA Raigarh, Jashpur } \\
\text { Korba districts of } \\
\text { Chhattisgarh, 1986, type I }\end{array}$ & $\begin{array}{l}\text { Poor people living in the } \\
\text { catchment area of the } 92 \\
\text { rural and health centres and } \\
\text { hostel students }\end{array}$ & $\begin{array}{l}\text { Hospitalization charges } \\
\text { up to Rs } 5000\end{array}$ & Rs 20/per person \\
\hline $\begin{array}{l}\text { SEWA, } 11 \text { districts of } \\
\text { Gujarat, Bihar, Tamil } \\
\text { Nadu and Rajasthan 1992, } \\
\text { type III }\end{array}$ & $\begin{array}{l}\text { SEWA Union women } \\
\text { members (urban and rural), } \\
\text { plus their husbands living in } \\
11 \text { districts }\end{array}$ & $\begin{array}{l}\text { Hospitalization costs up } \\
\text { to Rs 6,000; life: Rs } \\
\text { 20,000 natural death; } \\
\text { accidental death: Rs } \\
\text { 60,000; maternity: Rs } \\
\text { 300/child ( } \max 2 \\
\text { children). }\end{array}$ & $\begin{array}{l}125 \text { per person per year, Rs } \\
100 \text { for spouse, Rs } 100 \text { for } \\
\text { two children }\end{array}$ \\
\hline
\end{tabular}




\section{DISCUSSION}

\section{MHI frame work}

Evolving from the small credit offerings arena, MHI is driven by a small group of individuals. Based on the concept of social capital, these groups come in handy during hardships for low-income populations. As community-based financing programs have demonstrated an impressive track record in supporting the local population, low income families are more inclined toward these community-based groups instead of relying on national or regional health insurance policies. ${ }^{9}$

Low income families face an uphill battle in winning an insurance policy due to lower income, higher health risk, and greater default rates. Consequently, the disadvantaged populations are left to fend for themselves (Dror, Radermacher, Koren, 2007). MHI addresses these concerns by allowing the poor families to express their needs and priorities in terms of offerings. ${ }^{10-11}$

\section{Understanding micro health insurance}

The key features of micro health insurance are; (a) that the premium is prepaid on a regular basis before the illness-related event occurs and (b) that the premium is affordable to low-income populations. Like any insurance, MHI units apply risk pooling between good and bad risks and the membership is generally voluntary. $^{12}$

\section{Models for delivering micro-health insurance}

Due to the limited income of the target population, the prices of micro-insurance products are a crucial element in determining uptake. The cost of acquisition and delivery is a significant determinate of pricing. A GOI consultative group report outlines four different model approaches for delivering micro-insurance.

Partner-agent model (type 1): Insurers utilize micro finance institution's delivery system which provides sales and basic services to insurer and limited administrative burden for the micro institutions.

Full service model (type 2): The provider is responsible for product design, sales, servicing, and claims assessment and the insurers are responsible for all insurance-related costs and losses along with the profit incurred.

Community based model/mutual model (type 3): The policy holders own and manage the insurance program, and collaborate with health care providers like Hospitals, nursing homes etc.
Provider model (type 4): The hospitals play roles of both insurers and service provider, who offer the policies to individuals or groups. ${ }^{13,14}$

\section{Managing risks and challenges for extending health Insurance to poor}

The major technical risks encountered in insurance are moral hazard, adverse selection and fraud, these risks are seen in all types of insurance, but the subjective nature of the health risks makes health insurance more vulnerable as compared to other insurance like life or property. Designing health Insurance for the poor requires a deeper analysis, so as to accurately cover most of the significant health events and related expenditures while simultaneously keeping the premium low and affordable for the poor, can pose challenges to MHI. According to Radermacher, Dror and Noble, the four aspects to be considered when offering MHI products to ensure sustainability are: product manufacturing, product sales, product servicing and the maintenance of long-term stability. ${ }^{15}$

The development of linkages with government interventions, other micro-insurance schemes, healthcare and other service providers, social security institutions, social assistance programmes, etc. may strengthen the sustainability of the schemes as well as enhance their effectiveness. $^{16}$

With the above summarization of all the studies and programs providing financial benefits to the low income households, through MHI schemes, we would like to provide a hypothetical model, i.e. type 1 model including the insurer, community and service provider chain in dentistry as well, to reduce the financial burden and providing the oral health benefits to low income household of the society. So that we can achieve the India's Goal of SDG, to provide good oral health and well-being to community irrespective of the social and economic class.

The PRISMA checklist was utilized to report this systematic review, which can be considered strength of this study.

\section{Limitations}

Our review points to a narrow evidence based on the information gathered from the articles and schemes involved, the biggest limitation is the unavailability of the micro health insurance programs and schemes in the field of dentistry, still we have tried our best to provide a hypothetical model of MHI which can be implemented in dentistry.

\section{CONCLUSION}

It has been stated earlier that fee for service was the first form of payment that existed from the beginning. 
However, due to the problems faced by the patients in coughing up the cost of the treatment at a single shot, other forms of payment like insurance is intended to give a breathing space for the patients came into existence. Today, even the healthcare services providing outdoor patient department (OPD) visits are covered under the various insurance schemes available. This study is an attempt to illustrate all the available forms of $\mathrm{MHI}$ payment offerings are a promising way to mitigate the risks of disease and ill health, which are disproportionately borne by the poorest citizens. Access to $\mathrm{MHI}$ reduces out-of-pocket health spending, especially for catastrophic oral health events, and improves access to quality oral care for those who are insured.

Funding: No funding sources

Conflict of interest: None declared

Ethical approval: Not required

\section{REFERENCES}

1. Pauly MV, Zweifel P, Scheffler RM, Preker AS, Bassett M. Private health insurance in developing countries. Health Aff. 2006;2:369-79.

2. Xu K, Evans DB, Kawabata K, Zeramdini R, Klavus J, Murray CJ. Household catastrophic health expenditure: a multicountry analysis. Lancet. 2003;362:111-7.

3. Ranson MK, Sinha T, Chatterjee M, Gandhi F, Jayswal R, Patel F, et al. Equitable utilisation of Indian community based health insurance scheme among its rural membership: cluster randomised controlled trial. BMJ. 2007;334:1309-12.

4. Dror DM, Radermacher R, Khadilkar SB, Schout P, Hay FX, Singh A. Microinsurance: innovations in low-cost health insurance. Health Affairs. 2009;28:1788-98.

5. Davenport C, Elley K, Salas C, Taylor-Weetman CL, Fry-Smith A, Bryan S. The clinical effectiveness and cost-effectiveness of routine dental checks: a systematic review and economic evaluation. Health Technol Assess. 2003;7(7):1127.

6. Anita J. Emerging Health Insurance in India-An overview. In: 10th Global Conference of Actuaries. 2008;81-97.
7. Devadasan N, Criel B, Van Damme W, Lefevre P, Manoharan S, Van der Stuyft P. Community health insurance schemes \& patient satisfaction-evidence from India. Indian J Med Res. 2011;133(1):40.

8. Michielsen J, Criel B, Devadasan N, Soors W, Wouters E, Meulemans H. Can health insurance improve access to quality care for the Indian poor?. Int J Quality Health Care. 2011;23(4):471-86.

9. Ranson M. Reduction of catastrophic health care expenditures by a community based health insurance scheme in Gujarat, India: current experiences and challenges. Bull World Health Organ. 2002;80:613-21.

10. Balarajan Y, Selvaraj S, Subramanian SV. Health care and equity in India. Lancet. 2011;377(9764):505-15.

11. Dror DM, Radermacher R, Khadilkar SB, Schout P, Hay FX, Singh A, et al. Microinsurance: innovations in low-cost health insurance. Health Affairs. 2009;28(6):1788-98.

12. Ahuja R. Health insurance for the poor in India. Indian Council for Research on International Economic Relations. 2004;1-28.

13. Lu C, Chin B, Lewandowski JL, Basinga $P$, Hirschhorn LR, Hill K, Murray M, Binagwaho A. Towards universal health coverage: an evaluation of Rwanda Mutuelles in its first eight years. PLoS One. 2012;7(6):e39282.

14. Haddad S, Ridde V, Yacoubou I, Mák G, Gbetié M. An evaluation of the outcomes of mutual health organizations in Benin. PLoS One. 2012;7:e47136.

15. Roth J, Ramm G. Microinsurance demand and market prospects: India. Available at: http://www.findevgateway.org/library/microinsuran ce-demand-and-market-prospects-india. Accessed on 6 January 2019.

16. Berman P, Ahuja R, Bhandari L. The impoverishing effect of healthcare payments in India: new methodology and findings. Economic and Political Weekly. 2010;65-71.

Cite this article as: Hakeem NEF, Eshwar S, Srivastava BK, Jain V. Micro-health insurance in dentistry: the road less travelled. Int J Community Med Public Health 2019;6:1364-8. 